\title{
室内気候に関与する材料の吸放湿について
}

$\begin{array}{cccc}\text { 正会員 堀 江 悟 郎* } \\ \text { 同 } \text { ○江 } & \text { 口 和 雄** }\end{array}$

§1. 室内空気の水蒸気圧の変動を予㨽する為の基礎 資料として、室内空気に接する材料の吸放湿量について 䋡討する。今回は主として軟質瀻維板について報告す 万。

\section{§2. 平衡特性について}

材料の吸放湿速度を定める為にまず始に材料表面での 湿压が取上げられる（材料表面が平衡すべき空気の水蒸 気密度を湿圧々呼び、てれはさらに材料内部に迄搪大し て“材料の湿圧”として表現する。又正しくは水蒸気分 㾏であるが以下に於てはすべて密度で表わす)。一般に 材料の湿圧は温度と含湿率との函数であり、従来平衡特 性として実験的にいくつかの式が出されている。てれ等 はいずれも空気の混在しない状態か、又は非常に長時間 を費やして到達した平衡点を押えている。もちろん材料 本来の性質として、これは正しい测定であるが、室内気 候に関与する吸放湿を考光る時、ての平衡状態を基準と して良いかは疑問である。それは平衡に達するに長時間 を要する原因が熱伝導と対比して考劣た時、単に透湿率 の小さい為のおくれではなく、例えば吸着から吸蔵へと の過程が合まれる様な特有の複雑な機構による為だと考 えられるからである。

実験 [1] 恒湿槽内で到達する平衡

硫酸溶液を用いた恒湿槽 ${ }^{11}$ につて従来行われたと同 様な方法によつて平衡特性を調べた。用いた試料を第 1 表に示す。測定の順序及び要した時間を第 2 表に示す。 初わの加湿過程では 6 時間で重量変化のなくなつた時

第 1 表 恒湿槽での実験に用いた試料

\begin{tabular}{|c|c|c|c|}
\hline \multicolumn{4}{|c|}{ 材種：軟翼維繊板 苫 $12 \mathrm{~mm}$} \\
\hline 記号 & $\begin{array}{l}\text { 寸 法 } \\
(\mathrm{mm})\end{array}$ & $\begin{array}{c}\text { 表面より䉼湿 } \\
\text { 面迄の愿ざ } \\
(\mathrm{mm})\end{array}$ & 摘 \\
\hline $\mathrm{T}_{1}$ & $6 \times 50 \times 50$ & 3 & 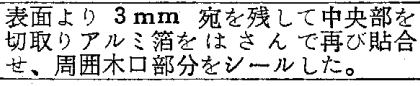 \\
\hline $\mathbf{T}_{2}$ & $12 \times$ & 6 & 周囲木口部分をアルミ䇴にンール。 \\
\hline $\mathbf{T}_{3}$ & $12 \times$ & 6 & シールなし。 \\
\hline$T_{4}$ & $12 \times$ & 12 & $\begin{array}{l}\text { 周囲木口部分及び片面 (網目側) をア } \\
\text { ルミ箔にてンール。 }\end{array}$ \\
\hline
\end{tabular}

交献1) 北海道爷部 36 年 8 月発表予定

\begin{tabular}{|c|c|c|c|c|c|c|c|c|c|c|c|}
\hline 第 2 表 & 加 & 㕲 & & 湿 & & 渮 & & 湿 & & 加湿|減湿 & 㲦燥 \\
\hline 相対湿度 (\%) & $\begin{array}{l}25 \\
1 \\
35 \\
\end{array}$ & \begin{tabular}{|c|}
35 \\
$\downarrow$ \\
50
\end{tabular} & \begin{tabular}{|c|}
50 \\
$\downarrow$ \\
65
\end{tabular} & \begin{tabular}{|c|}
65 \\
$\downarrow$ \\
75 \\
\end{tabular} & $\begin{array}{c}75 \\
\downarrow \\
90 \\
\end{array}$ & \begin{tabular}{|c|}
90 \\
$\downarrow$ \\
75
\end{tabular} & \begin{tabular}{|c|}
75 \\
$\downarrow$ \\
65 \\
\end{tabular} & $\begin{array}{c}65 \\
\downarrow \\
50\end{array}$ & \begin{tabular}{|c|}
50 \\
1 \\
35
\end{tabular} & \begin{tabular}{|c|c|c|c|c|}
35 & 65 & \\
$\downarrow$ & $\downarrow$ & \\
65 & & 35 & 絢 \\
\end{tabular} & $\begin{array}{c}35 \\
1 \\
\text { 絶乾 }\end{array}$ \\
\hline 測定 & 1 & 4 & 3 & 4 & 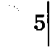 & 9 & 7 & 8 & 9 & 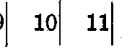 & 12 \\
\hline 所要時間 (h) & 35 & 47 & 58 & 84 & 100 & 147 & 140 & 153 & 144 & \begin{tabular}{|l|l|}
140 & 143 \\
\end{tabular} & 24 \\
\hline
\end{tabular}

* 北海道大学教授 $* *$ 同 助手
を以て打切つたが時間が不足である事に気が付き後半か らは24時間で重量変化をしない状態を一応の目標と し、大略 140 時間を測定の単位とした。温度は $20^{\circ} \mathrm{C} \pm$ $0.5^{\circ} \mathrm{C}$ 。各測定終了時に硫酸溶液の比重を測定し平衡相 対湿度を補正した。最後に $100^{\circ} \mathrm{C} て ゙$ 絶乾とした。実験 の結果を第 1 図及び第 2 図に示す。 $T_{1}, T_{2}, T_{3}$ は同じ変

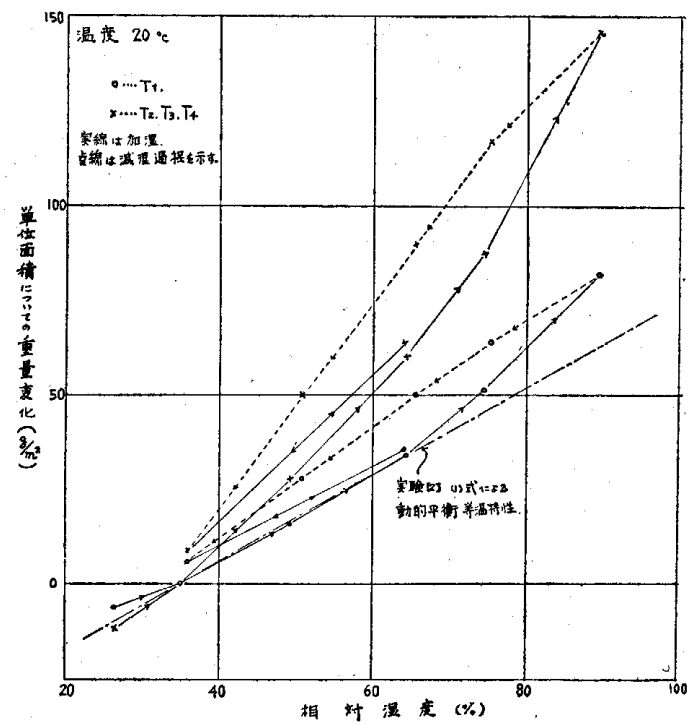

第 1 図 軟質瀻維板の平衡特性 （初めの $35 \%$ での值を 0 と押えた）

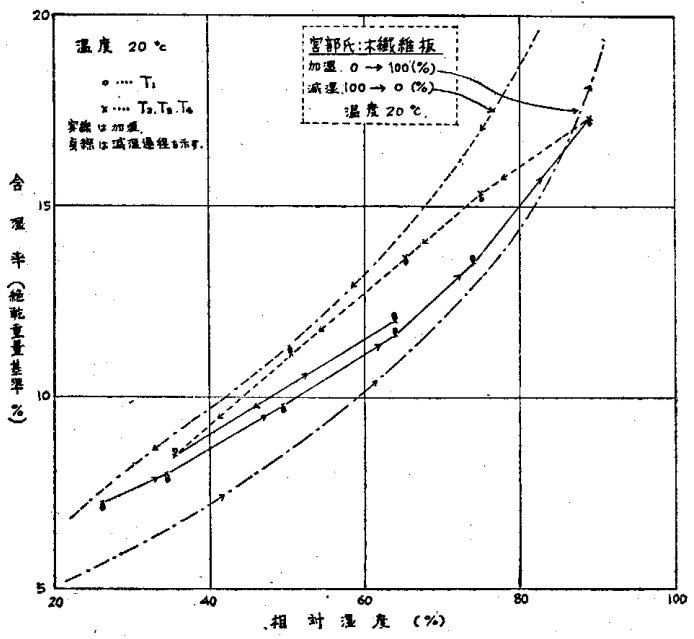

第 2 図 軟質纎維板の平衡特性

化をたどつた。これよりここで押えた最終時に於ては湿 気の分布は体積に対して一樣であつたと見て良いであろ う。どの試料についても所謂履歴が見られる。加湿時で さらに時間をかければてのループは狭くなると見られる が非常に長時間の後に於て果して履歴現象が消滅するか 否かはことでは結論を下せない。しかし $\mathrm{T}_{3}$ も同じ様な 
経過をたどる事よりとてでの履歴は嬮みに対するおくれ ではなく体積全般についての問題と考㝋て良いであろ う。又最後行つた $35 \rightarrow 65 \rightarrow 35$ の変化では履歴が見ら れなかつた、ての時与光た湿度差が大きいから（通常 10 15\% がての場合は 30\%) 単に高湿時に於て履歴が 出やすいと即断する事は出来ない。

実験 [2] 密閉箱内での動的平衡

すでに報告した密閉箱内2)で温度、湿度及び材料重量 の変化がなくなり平衡したと見られる状態を後汇述べる 理由から、実験 [1]で求められた平衡と区別する為とれ を動的平衡と呼ぶ事にする。実験に用いた武料は実験 [1] の試料と同じ板から切取つた。寸法等を第 3 表に示

第 3 表 密閉箱内での実験（実験 3）に用いた試料

\begin{tabular}{|c|c|c|c|c|c|c|}
\hline 記号 & $T / 1$ & $T / 2$ & $\mathrm{~T} / 4$ & $\mathrm{~T} / 8$ & $\mathrm{~T} / 16$ & $\mid \begin{array}{l}\text { 梠種、密度は第 } 1 \text { 表 } \\
\text { 厚さははすざて原材 }\end{array}$ \\
\hline $\begin{array}{c}\text { 寸法 } \\
(\mathrm{mm})\end{array}$ & & $400\rangle$ & $200 \times 200$ & $200 \times 100$ & $100 \times 100$ & 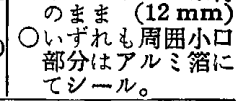 \\
\hline
\end{tabular}

す。実験は初め試料を入れた密閉箱を $25^{\circ} \mathrm{C} \sim 30^{\circ} \mathrm{C} の 一$ 定温度に保ち(約 12 時間) 温湿度及び武料重量が一定 した事を見定めてから密閉箱の外部より冷却・加熱・冷 却・加熱と 4 回の変化を与えた。途中での空気の温度、 湿度及び試料重量の変化屾自記記録され、温湿度及び重 量の変化がなくなつたと見られる所で次の変化に移つ た。各変化での初期の動的平衡点から次の平衡点迄の重 量変化 (吸放湿量) $\Delta \omega$ と、温度変化 $\Delta \theta$, 相対湿度変化 $\Delta \varphi$ の関係についててれを整理すると ${ }^{3} 30 \sim 70 \%$ の範囲 では次式に示す直線式で表わす事が出来る。

$$
\Delta \omega=\zeta^{\prime} \cdot \Delta \varphi-\nu^{\prime} \cdot \Delta \theta
$$

$\Delta \omega$ : 材料の単位面積当りの吸（放）湿量 $\left(\mathrm{g} / \mathrm{m}^{2}\right)$ $\zeta^{\prime}$ : 等温で相対湿度 $(\varphi)$ が $1 \%$ 増加した時の単 位面積当りの放（吸）湿量 $\left(\mathrm{g} / \mathrm{m}^{2} \cdot \%\right)$

$\nu^{\prime}$ : 等相対湿度で温度が $1^{\circ} \mathrm{C}$ 上舁した時の単位 面積当りの放 (吸) 湿量 $\left(\mathrm{g} / \mathrm{m}^{2}\left({ }^{\circ} \mathrm{C}\right)\right)$

ここでは $\zeta^{\prime}=1.15, \nu^{\prime}=0.184$ となつた 式で表わせる事は一実験中では冷却 (加湿)、加熱（減 湿）の繰返しにより実験 [1] で現われた如き履歴がない 事を意味する。もし重量の変化をその絶対值を基準にす ると同一材料で実験のたびに異つた平衡重量となつた が、重量の変化分のみを取上げる時（1）式が成立つ。 第 1 应に等温時での (1) 式を鎖線にて示し実験 $[1]$ の結 果と対比すると、ことで動的平衡と呼んだものは実験 [1] に対し一見厚さ $3 \mathrm{~mm}$ 程度に相当するかの如くで あるが両者の関連は次の実験によつて明らかにされる。

文㚋2) 論文報告集第 63 号, 66 号

交献 堀江：居住室における温度および湿度に関する研究 1961 年 5 月

実験 [3]実験 [2] では面樍を変えたが厚さはすべ て一定であつた。とてでは実験 [2] で用いた武料 $\mathrm{T} / 2$ に第 4 表の加工をして実験を行つた。実験の方法は実験
第 4 表 密閉箱内での実験（実験 3) に 用いた試料

\begin{tabular}{|c|c|c|}
\hline 記号 & 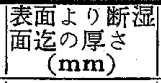 & 摘 \\
\hline $\mathrm{T} / 2 \mathrm{~A}$ & 12 & $\begin{array}{l}\text { T/2の表面をアルミ箔にて } \\
\text { シールした }\end{array}$ \\
\hline $\mathrm{T} / 2 \mathrm{~B}$ & 12 & $\begin{array}{l}\mathrm{T} / 2 \text { の裹面（網目側）をン } \\
\text { ールした }\end{array}$ \\
\hline $\mathrm{T} / 2 \mathrm{C}$ & 6 & $\begin{array}{l}\mathrm{T} / 2 \text { の表裹共上下をンール } \\
\text { した (第 } 3 \text { 参照) }\end{array}$ \\
\hline
\end{tabular}

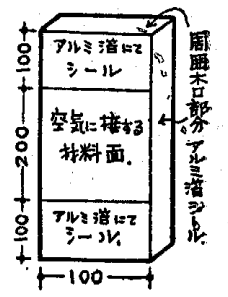

[2]と同じである。但しアルそ箔の貼付は実験装置全体に ビニール幕を被せ（密閉箱はこの時蓋を開けてある） 12 時間程度一定温湿度に保つた後、手早く行つた。実験の 結果を(1) 式を使つて 検討すると T/2C は良く適合し た。これは空気に接する部分からシールされた部分への （放湿の時はての逆）湿気の平面的な拡散は動的平衡の 場合殆んどない事を示す。 T/2 A, T/2 B の両者の間に は差がなかつたが、両者共実験 [2] に比べ約 1.3 倍の 吸放湿量を示した。即ち（1）式での係数 $\zeta^{\prime}, \nu^{\prime}$ ををれ ぞれ 1.3 倍にすると良く適合する。

\$3. 実験 [2] での動的平衡は実験 [1]に比べその 体積当りの重量変化が約 5 割程度でしかなかつたが、こ の約 5 割の水苲気は実験 [3] の結果より、材料の表面に のみ集中しているとは考兄られず、又材料中に一様に分 布しているとも考元られない。材料の厚みの方向滵度 勾配をもつていると推測される。それは不平衡の状態で あるが、それ以後は非常に速度が㧍そいと考光られる。 しかし単に透湿拡散のおくれと考光るならば見掛け上の 履歴現象は当然出て来なければならない。或密度勾配 (又は密度差）以下に於て拡散速度が扔そくなるとの考 え方は、毛管凝縮によつて或程度説明出来るのではない かと考光られるが、こてではての問題についててれ以上 立入る事をやめる。実験 [2][3] で求められた動的平衡 は非常に長時間の後には実験 [1] での平衡に澾するであ ろうと想像される。しかし通常の屋内気候での温湿度変 化の周期を考え、又目的とする所を考慮すればこの様な 最終の平衡状態を基準注るる事が妥当であるが疑わし い。もちろん両者の（実験 [1]と［2]との）関係が適 確に表現されることは望ましいが、いずれにしろそれは 非常に複雑なものとなるであろう。

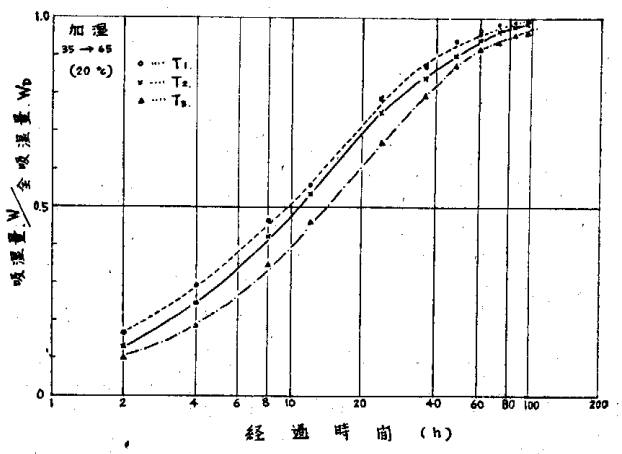

第 4 図 (1) 恒湿槽内での吸湿過程 


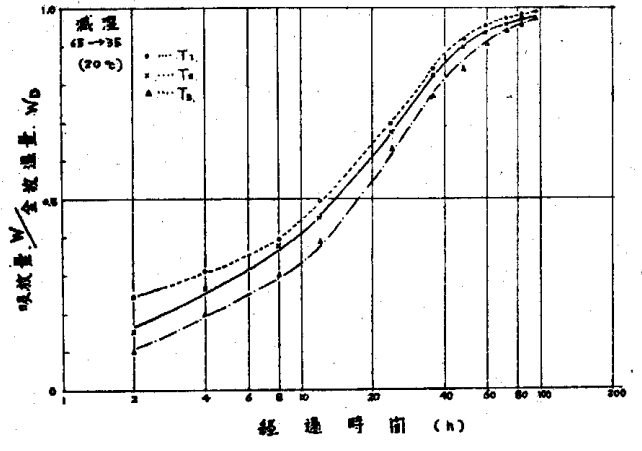

第 4 図（2） 恒湿槽内での放湿過程

\$4. 木材の吸放湿に於て熱伝導の式がそのまま適用 出来ない事はすでに知られているが、しかし近似出来な

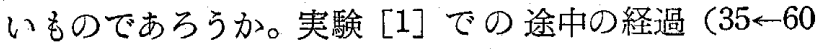
及び $60 \rightarrow 35)$ を第 4 図俰示す。大勢として平板の冷却 の際の熱放散に似ている。そてで今迄述べた平衡特性の 複雑さを一応無視して熱后導の式を適用して見る。材料 内部での透湿を次式の如く仮定する。

$$
W=\lambda^{\prime}\left(\frac{\partial \sigma_{m}}{\partial x}\right) \cdot S \cdot d t
$$

ここに $W$ : 透湿量 $(\mathrm{gr}), S$ : 表面積 $\left(\mathrm{m}^{2}\right) 、 \lambda^{\prime}:$ 透湿率 $\left[\mathrm{g} / \mathrm{mh}\left(\mathrm{g} / \mathrm{m}^{3}\right)\right], \partial \sigma_{m} / \partial x:$ 湿圧勾配 $\left[\left(\mathrm{g} / \mathrm{m}^{3}\right) / \mathrm{m}\right]$, 又材 料の平衡特性を(1) 式の形を借り次式の如く表わす。

$$
\omega=\zeta \cdot \varphi_{m}-\nu \cdot \theta_{m}-C
$$

（3）式より逆に材料の湿压を次式で表わせると仮定す る。

$$
\sigma_{m}=\frac{\sigma_{s m}}{100 \cdot \zeta}\left[\omega+\nu \theta_{m}+C\right]
$$

とこに、

$$
\begin{aligned}
& \omega: \text { 湿気密度 }\left(\mathrm{g} / \mathrm{m}^{3}\right) \\
& \zeta, \nu: \text { (1) 式の場合に準ず。但しいずれも単位体積 } \\
& \text { についてである。 } \\
& \theta_{m} \text { : 考えている場所の材料の温度 }\left({ }^{\circ} \mathrm{C}\right) \\
& \varphi_{m}: \sigma_{m} / \sigma_{s m} \times 100 \quad(\%) \\
& \sigma_{s m}: \theta_{m} \text { に対する空気の飽和絶対湿度 }\left(\mathrm{g} / \mathrm{m}^{3}\right) \\
& C: \text { 常数 } \\
& \text { (2)（4）式より基本式として次式が導かれる。 } \\
& \frac{\partial \sigma_{m}}{\partial t}=\frac{\sigma_{s m}}{100 \cdot \zeta} \cdot \lambda^{\prime}\left(\frac{\partial^{2} \sigma_{m}}{\partial x^{2}}\right) \\
& +\left[\varphi_{m} \cdot\left(\sigma_{s}+\delta\right) \cdot r+\frac{\sigma_{s m}}{100 \cdot \zeta} \cdot \nu\right] \frac{\partial \theta_{m}}{\partial t}
\end{aligned}
$$

但し $\sigma_{s m}=\alpha \cdot e^{\gamma \theta}-\delta$ とおき（ $(\alpha=6.676, \gamma=0.0524, \delta$ $=1.825$ として $0 \sim 30^{\circ} \mathrm{C}$ は允分近似出来る) $\frac{\partial \sigma_{s m}}{\partial \theta}$ を処 理した。

温度変化のない場合には次式となる。

$$
\frac{\partial \sigma_{m}}{\partial t}=\frac{\sigma_{s m}}{100} \cdot \frac{\lambda^{\prime}}{\zeta}\left(\frac{\partial^{2} \sigma_{m}}{\partial x^{2}}\right)
$$

熱伝導との対応は次の如くなる。

$$
a \hookleftarrow a^{\prime}=\lambda^{\prime} / \frac{100 \cdot \zeta}{\sigma_{s m}} \quad(7) \quad h \hookleftarrow h^{\prime}=\beta / \lambda^{\prime}
$$

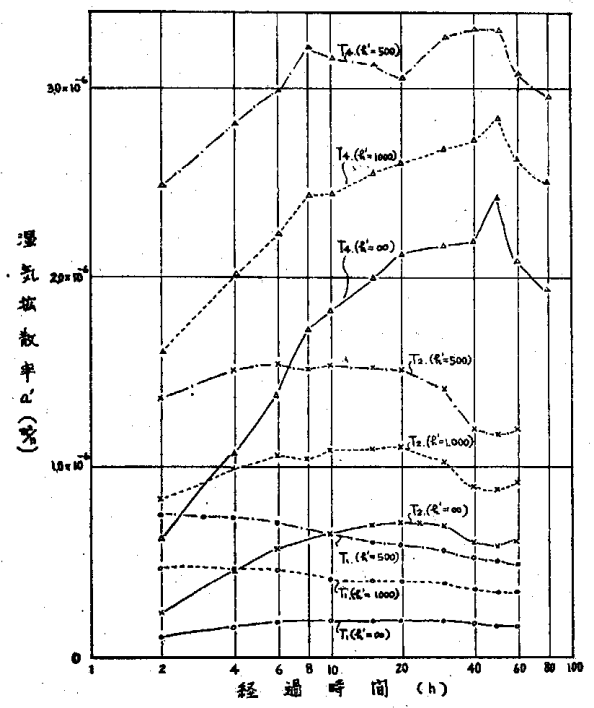

第 5 図 実測値より算出された $a^{\prime}$

$\beta:$ 湿気伀達率 $\left[\mathrm{g} / \mathrm{m}^{2} \cdot \mathrm{h}\left(\mathrm{g} / \mathrm{m}^{3}\right)\right]$

実験 [1] で実測された $35 \rightarrow 65$ の結果に対して $h^{\prime}=$ $\infty, h^{\prime}=1,000, h^{\prime}=500$ の三通の仮定で線図 ${ }^{4)}$ 上り求め た $a^{\prime}$ の值を第 5 図に示す。今 (7) によつて、 $\lambda^{\prime}=0.02$, $\zeta=310$ (実験での最終平衡值による) とすれば $a^{\prime}$ は $11.2 \times 10^{-6}$ となり、第 5 図の示す数值と全く合はない。 最も重量な点は第 5 図に見られる如く愿さによつて $a^{\prime}$ が異る事である。 $\mathrm{T}_{1} \mathrm{~T}_{2} \mathrm{~T}_{3}$ は厚さの相違以外はすべて同 じであると考えられるから実験の結果を次元的に解析し た。第 4 図に於て同じ $W / W_{D}$ 亿対する各試料の時間の 值を読取る方法と、測定值が 10 時間以上では大体指数 函数の一項で表わすととが出来るからこの指数の比から 求める方法と両者を行つた。これは実験 [1]でのすべて の変化について行なつた。その結果ての実験の場合 WI $W_{D}$ をe $e$ の無限級数に展開した時その指数は $z \times l^{-0.2}$ $\times t(z$ は常数、 $t$ は時間 $l$ は厚さ）とならなければなら ない。てれより比較的簡単と見られる等温の場合です ら、熱云導の式は適用出来ない事を再確認した。

\section{§5. 略算法の試み}

室内気候関与する吸放湿量を求める際、要求される 精度及びその実用性からして、厳密な解式を追求する事 は将来にゆずり、こてでは略算法について試みる。実験 [2] で求められた動的平衡が通常の室内気候の範囲で起 り得る平衡状態と考光しれを基準とし、式 (1) 上り表面 の湿圧を求める。今初めの動的平衡点での温度、湿度を 0 とし、温湿度共にてれを基準として測る事にすれば (1) 式は

$\omega^{\prime}=\zeta^{\prime} \cdot \varphi-\nu^{\prime} \cdot \theta$ となる。乙れより表面の湿圧は

$$
\sigma_{m}^{\prime}=\frac{\sigma_{s m^{\prime}}}{100 \zeta^{\prime}}\left(\omega^{\prime}+\nu^{\prime} \theta_{m}\right)
$$

と仮定する。ととに

交献辛) 川下研介：熱伝導諭 

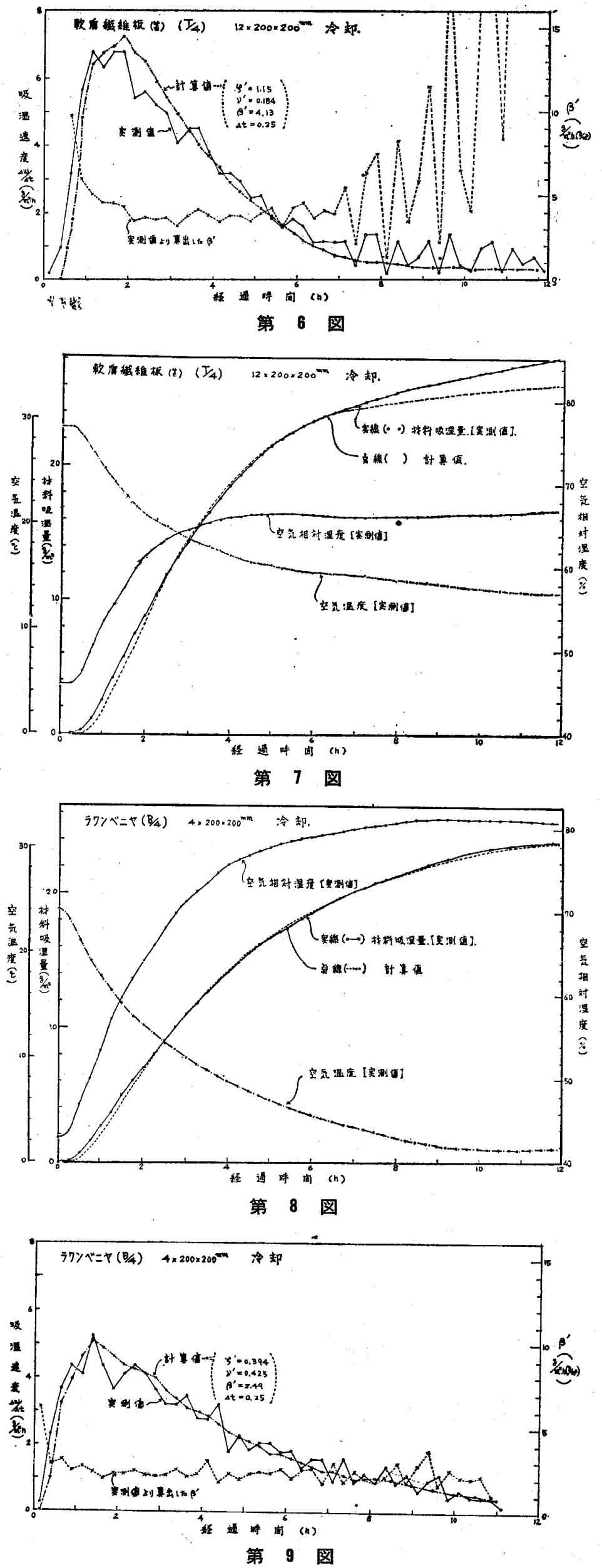

$\omega^{\prime}$ : 単位面積当りの吸（放）湿量 $\left(\mathrm{g} / \mathrm{m}^{2}\right)$ 但し初めの動的平衡点を0 と押える。 $\sigma_{m}^{\prime}:$ 材料表面での湿圧 $\left(\mathrm{g} / \mathrm{m}^{3}\right)$ $\sigma_{s m^{\prime}}: \theta_{m}$ に対応する飽和絶対湿度 $\left(\mathrm{g} / \mathrm{m}^{3}\right)$

$\theta_{m}:$ 材料表面の温度 $\left({ }^{\circ} \mathrm{C}\right)$

$\zeta^{\prime}, \nu^{\prime}:$ 式 (1) の表示に同じ

もちろんこの仮定は一つの変化の初めと終りの 動的平衡状態に於ては成立つてもその途中では成 立たない事は、すでにミ3 で述べた如く動的平衡 状態が表面にのみ湿気の集中した状態ではなかつ た事から明らかであるが、その経過の途中での湿 気分布を知る手分汃りとしても、一応との仮定を 置く。又吸放湿の速度は空気の水蒸気圧 $\sigma_{a}$ と湿 圧 $\sigma_{m}^{\prime}$ との差に比例するとして、比例常数を $\beta^{\prime}$ とする。

$$
\frac{d \omega^{\prime}}{d t}=\beta^{\prime}\left(\sigma_{a}-\sigma_{m}^{\prime}\right)
$$

(10) 式を用いて実験 [2] の測定値より $\beta^{\prime}$ を 算出した。的はもちろんとてでの湿気伝達率であ り次元は $\left[\mathrm{g} / \mathrm{m}^{2} \mathrm{~h}\left(\mathrm{~g} / \mathrm{m}^{3}\right)\right]$ であるが上述の仮定よ りその意味する本来の値とは異る。

実験 [2]より実測された $d \omega^{\prime} / d t$ と算出された $\beta^{\prime}$ の一例を第 6 図に示す。各サイズについて冷 却・加熱とも $\beta^{\prime}$ の傾向はすべて同様であり初めの 2 時間以後の 5 時間程はほぽ定值を保ちその值 は 3.0 4.3 であつた。この様に非常に雑な仮定 の下においても初期の速度の大きい所で各実験共 ほぼ似た值となつた事が注目される。これはこの 時期では吸湿されだ水蒸気の表面への集中（放湿 ではこの逆）を示し内部への拡散は相当に遅れた 時期から起つていると考元られる。 $\beta^{\prime}$ が定まれば 吸放湿量を逆化計算する事が出来る。温度及び湿 度変化を支元られたものとして数值計算による。 第 6 図の例について計算した結果を同図及び第 7 . 図に示した。7 時間以後に於て計算值が小さく出 るのは上述の如く内部への透湿を示していると考 えられる。初期のおくれ時間 $\Delta t$ を小さく取る 事により多少良くなるが $\beta^{\prime}$ の值が初期から一定 ではなかつたから正確に同じにはならない。軟質 繊維板ではこの略算法は決して満足すべきもので はないが実験 $[2] の$ 際同時に試べられたベニヤ(ラ ワン $4 \mathrm{~mm}$ )で注良く略算值が合う。実験は $400 \times$ 400 記号 $(\mathrm{B} / 1)$ ，皮び $200 \times 200$ 記号 (B/4) に ついて行い軟質繊維板の場合と同じ好理方法をと つた。実測の結果ならびに数値計算の結果の 1 例 を第 8,9 図に示した。 